\title{
Dysfunctions of NPOs and NGOs in Poland in the Global Context: Some International Comparisons
}

\author{
Janusz Fudaliński
}

Research Design \& Methods: The article is based on the literature review as well as the synthetic review of the conducted research and data in the field of NPOs and NGOs.

Findings: On the basis of western models, which can be treated as benchmarks, dysfunctions of NPOs and NGOs in Poland can be reduced. It will lead to more dynamics of non-profit organizations growth in Poland. It will result in greater level of internationalization of this sector in Poland.

Implications \& Recommendations: Indication of directions of activities for stimulating internationalization and globalization of organization's operations in the third sector in Poland seems to be an important issues as it is a gradually revealing and growing tendency in this respect.

Contribution \& Value Added: It also requires an analysis, especially with regard to the Polish conditions, of potential dysfunctions of non-profit organizations whose existence may slow down or even limit the possibility of operations in an international or global scope.

Article type: research paper

Keywords: NPOs; NGOs; internationalisation; globalisation; non-profit

JEL codes: HOO, L30, L31

Published by Centre for Strategic and International Entrepreneurship - Krakow, Poland

\section{Suggested citation:}

Fudaliński, J. (2014). Dysfunctions of NPOs and NGOs in Poland in the Global Context: Some International Comparisons. Entrepreneurial Business and Economics Review, 2(1), 81-94. 


\section{INTRODUCTION}

The non-profit organizations (NPOs) and non-governmental organizations (NGOs) sector in Poland has been substantially developing and expanding research on international and global aspects of NPOs activity is a natural consequence of the growth (Fudaliński, 2013; Bogacz-Wojtanowska, 2011; Drucker, 1990). It should be noted, however, that due to the specific character of third sector organizations, the process of globalization and internationalization they experience differs from standard (or classic) pattern of development (Courtney, 2002). This is why research on determining factors is so important. It requires a thorough analysis, especially with regard to the Polish conditions, of potential dysfunctions of non-profit organizations which might slow down or even limit the possibility of their operations in an international or global scope. Therefore, it seems that indication of directions of activities for stimulating internationalization and globalization of organization's operations in the third sector in Poland is vital because Polish NPOs gradually reveal a growing tendency in this respect (Fudaliński, 2013).

\section{MATERIAL AND METHODS}

Therefore, the adopted purpose of the article is an initial diagnosis of the level of internationalization and globalization of non-profit organization sector in Poland, as well as indication of possible differences in this respect, reflected in selected well-developed countries. The proposed hypothesis assumes that the presence of potential development disproportions may be the result of existence of some dysfunctions whose identification is a starting point for activities initiating progress on the way to internationalization and globalization of NPOs sector in Poland.

The paper is based on a literature review as well as the synthetic review of the conducted research and data gathered in the field of NPOs.

\section{LITERATURE REVIEW AND DISCUSSION}

\section{The Essence of Internationalization and Globalization Processes}

Globalization and internationalization of organization's operations appears currently as a normal and rather common phenomenon (Breński \& Oleksiuk, 2008; Przybylska, 2005; Daszkiewicz \& Wach, 2012; Wach \& Wehrmann, 2014). It is worth paying attention to the reasons of the globalization and internationalization processes since not in every area (business domain) they took similar dynamics. The main reasons of the emergence of globalization include: technical, political, social and economic forces (Przybylska, 2013).

The reference to the roots of the globalization processes (Wach, 2012; Przybylska, 2005) reflects rather the specific nature of non-profit organization sector than just their imitative characteristics. In general, though not always, changes are initiated in the field of widely understood business ${ }^{1}$ and then the results are diffused into the two remaining sectors of economy. Therefore, phenomena of diffusion, globalization or imitation have

\footnotetext{
${ }^{1}$ At this point of the paper, the existence of three basic sectors of the economy is assumed: (1) the sphere of public organizations sector, (2) business sector and (3) non-profit organization sector.
} 
also influenced supranational activities of third sector organizations, although their importance and impact were slightly modified on the one hand, but on the other hand, they have also their specific, different effect on development dynamics of NPOs sector. This is particularly reflected in the changes of technological nature related to the occurrence of information society (Szczepankowska, 2011; Szymański, 2004).

The globalization can be also referred to as a revolution in communication and transportation, thanks to which goods, services, people and information can be transferred at long distances at much lower costs. Coordination of worldwide activities of both entire states and single companies was possible thanks to the development of information and communication technology (phone, fax, Internet and e-mail) (Szymański, 2004, p. 41). And IT development, apart from social changes, to a large extent determined the development of NPOs sector (Bebington et al. , 2007, p. 3). Thanks to the changes of political and legal framework the flow of both goods and people is no longer restricted by burdens of unnecessary documents and permits. Economic reasons, on the other hand, are the basis for creation and development of globalization, but in case of third sector mostly resulting social inequalities are emphasized and discussed. All above mentioned factors are becoming visible, which is exemplified in the emerging social movements initiated and integrated by realized on unusual so far scale exchange of information (Arab Springtime or African Springtime of the Peoples as sometimes it is called, or the case of ACTA).

Information society is a society in which information is a product perceived as a special intangible asset, perceived as equally or even more important than a traditional tangible asset (Wach, 2014). Information society development can be treated both as the cause of globalization (it is exactly because of it that internationalization was possible) and its result (as a result of globalization, more and more people were forced to use services related to storage, transmission and processing of information). Information processing and communication are the basis for creating national income in the information society and are the source of livelihood for most of the society. It is assumed that the term "information economy" can be used when at least $50 \%$ of national gross income is created within the IT sector.

Therefore, the society becomes an information society when it reaches the degree of development and scale and complication of social and economic development requiring the use of new techniques of gathering, processing, transferring and using huge amount of information generated by these processes (Breński \& Oleksiuk, 2008, pp.6567).

At present, Poland, with its third sector, is not ready to pass to the phase of information society or is rather at the beginning of the transition. Our country is at the 34th position among countries which are best adapted to transform into information society. Expenses in total (public and private) on technologies in our country are growing very slowly, they constitute approximately $3 \%$ of the GDP, which additionally delays the progress of globalization in Poland. Common access to the Internet is also an important aspect of information society, and in 2006 only $36 \%$ of households had Internet access, but this ratio is systematically growing and in 2011 it amounted to 66.6\% (GUS 2012, p. 99). This proves large dynamics of Internet availability, but also progress on the way to reach the status of information society, and also to a large extent to civil society. 


\section{Non-profit Organizations in the Global Context}

In the literature it is rare to encounter complex methods of measuring the process of globalization. There is, however, an index assessing the level of global integration, known as Globalization Index, or Kearney Index. In the broadest division the index distinguishes such factors as: economic integration (e.g. foreign direct investment), personal contacts (travels and international telephone conversations), technology (number of users of the Internet, number of safe servers), and political commitment (membership in international organizations, the number of embassies in a particular country). Thus it is assumed that the higher index value, the greater level of globalization of a given country is (Table 1).

Table 1. Ranking of regions according to Kearney index in the period 1995-2000

\begin{tabular}{|l|r|r|r|r|r|}
\hline \multicolumn{1}{|c|}{ Region } & Economy & Contacts & Technology & Policy & Kearney Index \\
\hline Western Europe & 1.7 & 1.3 & 1.1 & 4.6 & 6.0 \\
\hline North America & 1.0 & 0.9 & 2.1 & 4.6 & 5.8 \\
\hline South-East Asia & 1.6 & 0.7 & 0.3 & 3.0 & 3.8 \\
\hline Central-East Europe & 0.8 & 0.7 & 0.3 & 2.5 & 2.9 \\
\hline North Africa & 0.5 & 0.7 & 0.1 & 2.3 & 2.6 \\
\hline Latin America & 1.0 & 0.2 & 0.1 & 2.0 & 2.5 \\
\hline East Asia & 0.6 & 0.2 & 0.6 & 2.0 & 2.5 \\
\hline Central and South Africa & 0.6 & 0.6 & 0.5 & 2.1 & 2.3 \\
\hline South Asia & 0.2 & 0.3 & 0.0 & 1.9 & 1.9 \\
\hline
\end{tabular}

Source: own study based on (Rybiński, 2009, p.25).

In the years 1995-2000, in the ranking of countries the first five according to weighted Kearney index are: Ireland, Singapore, Switzerland, Sweden, Canada. Studies conducted in 2010 show the globalization index (Table 2) for selected countries in the world.

Table 2. Globalization index in 2010 by state

\begin{tabular}{|l|l|r|}
\hline Place & \multicolumn{1}{|c|}{ State } & \multicolumn{1}{|c|}{$\begin{array}{c}\text { Globalization } \\
\text { index 2010 }\end{array}$} \\
\hline 1 & Hong Kong & 7.48 \\
\hline 2 & Ireland & 7.34 \\
\hline 3 & Singapore & 6.78 \\
\hline 4 & Denmark & 5.93 \\
\hline 5 & Switzerland & 5.86 \\
\hline 6 & Belgium & 5.82 \\
\hline$\ldots$ & $\ldots$ & $\ldots$ \\
\hline 25 & Poland & 4.48 \\
\hline$\ldots$ & $\ldots$ & $\ldots$ \\
\hline 56 & Indonesia & 3.00 \\
\hline 57 & India & 2.96 \\
\hline 58 & Venezuela & 2.85 \\
\hline 59 & Algeria & 2.82 \\
\hline 60 & Iran & 2.27 \\
\hline
\end{tabular}

Source: own compilation based on (Ernst \& Young 2010). 
The need for changes in organizations is related to the dynamics of environment in which they operate. These changes occur in all sectors of the economy, including public benefit organizations (Gerencser et al. , 2008, p. 77) and they contribute to a much greater level of flexibility due to competitiveness requirements (Dworecki \& Romanowska, 2008, pp. 13-14; Kiendl-Wendner \& Wach, 2014), which more and more often also refer to non-profit organization sector. In other words, inevitably, the third sector and organizational formations will not only face the need to accept a flexible formula of activities, but also to adapt a broader view, comprising the professionalization of the management process (Fudaliński, 2013). It should be rather agreed that globalization has a tremendous impact on the society and at the same time it shows both positive and negative aspects. In this sense we can notice the specific role of third sector organizations which focus also on levelling its pejorative effects.

Along with globalization there appeared some important challenges for NGOs and NPOs. Among them we can mention: collapse of abilities of national governments, weakness of global institutions, new challenges of financial competition, new pressure on greater activities and responsibility, new forms of global poverty and crises (Domański, 2008, p. 247). At present, there is rather no other choice but to follow and struggle with trends of international or global nature, the core of the problem lies in properly diagnosing and assuming instruments of activities resulting in the capability of an organization to pursuit the adopted goals and then to survive and grow. And what is important, this does not relate only to the sphere of business, but also third sector organizations.

In Germany the third sector is characterized by large impact of the principle of subsidiarity, which in the local conditions is expressed as relative priority of nongovernmental organizations over public administration (Leś, 2010). Currently the sector of non-governmental organizations in Germany faces many problems. From the national point of view it should be mentioned that large disproportions appear between ever growing social needs and decreasing public resources. The increase in expenses on public goals has a strong effect on increased public debt. From the European perspective, on the other hand, the most important issue concerns full or partial exemption of social services from the EU regulations on freedom of competition (Balon, 2013). Another important issue is also the problem of inflow of social services from other EU countries, especially those newly approved (Domański, 2008, p. 247) and differences referring to globalization factors (Table 3).

At the moment of accession to the European Union in May 2004, Poland also entered a new stage of internationalization of the environment of non-profit organizations. The EU affected the process classified as elements of internationalization and globalization (Najda \& Wach, 2005); among the issues it influenced we can mention: opening uniform European market for entrepreneurs, building information society and information technology development, the ageing of societies and professional stimulation for older people, levelling differences in socio-economic development of regions of new EU member states by means of, among others, structural funds (financing), life-long education or other attempts at European integration (Tyrakowski, 2013, pp. 188, 250). Currently every eighth new work posts created in such countries as France or Germany is located within the third sector, which proves its importance. 
Table 3. Globalization factors: A comparison between Poland and Germany

\begin{tabular}{|c|c|c|}
\hline $\begin{array}{l}\text { Globalization } \\
\text { factor /Country }\end{array}$ & Poland & Germany \\
\hline $\begin{array}{l}\text { Organization } \\
\text { objectives }\end{array}$ & $\begin{array}{l}\text { mainly goals related to the core of } \\
\text { globalization: respect for energy } \\
\text { sources, environmental protection, } \\
\text { animals protection and protection of } \\
\text { personal rights and freedoms; actions } \\
\text { for the benefit of children, fight against } \\
\text { social pathologies; help for third world } \\
\text { countries, help for the victims of } \\
\text { natural disasters; }\end{array}$ & $\begin{array}{l}\text { first of all activities for own country, actions } \\
\text { for the benefit of levelling social differences; } \\
\text { one of the priorities is commitment to } \\
\text { helping children and teenagers; on the basis } \\
\text { of the principle of subsidiarity; }\end{array}$ \\
\hline $\begin{array}{l}\text { International } \\
\text { operations }\end{array}$ & $\begin{array}{l}\text { first of all actions within larger } \\
\text { organizational structures; participation } \\
\text { in humanitarian missions, aid } \\
\text { programmes for poorer countries; }\end{array}$ & $\begin{array}{l}\text { participation in humanitarian missions, } \\
\text { support for poorer countries; }\end{array}$ \\
\hline Partnership & $\begin{array}{l}\text { cooperation with organizations with a } \\
\text { similar profile of operations in other } \\
\text { countries, large role of foundations, } \\
\text { often activities of organizations } \\
\text { established under agreements } \\
\text { between countries; }\end{array}$ & $\begin{array}{l}\text { Iong history of non-governmental } \\
\text { organizations in Germany resulted in the fact } \\
\text { that there have been developed a broad } \\
\text { network of relations of German } \\
\text { organizations with those operating in other } \\
\text { countries, especially belonging to the } \\
\text { European Union, also with Poland (the result } \\
\text { of such co-operation is for instance the } \\
\text { Foundation for Polish-German } \\
\text { Reconciliation) }\end{array}$ \\
\hline $\begin{array}{l}\text { International } \\
\text { personnel }\end{array}$ & $\begin{array}{l}\text { non-governmental organizations } \\
\text { created in Poland benefit from help of } \\
\text { foreign employees or volunteers, } \\
\text { especially these organizations, } \\
\text { occupied with provision of services in } \\
\text { other countries (e.g. humanitarian } \\
\text { operations in Third World countries); }\end{array}$ & $\begin{array}{l}\text { thanks to membership of Germany in the } \\
\text { European Union there is smooth flow of } \\
\text { human capital from other countries, which is } \\
\text { visible also in non-profit organizations; }\end{array}$ \\
\hline $\begin{array}{l}\text { Foreign sources } \\
\text { of financing }\end{array}$ & $\begin{array}{l}\text { above all European funds; and also } \\
\text { other foreign financial means acquired, } \\
\text { among others, from embassies (British, } \\
\text { U.S., Canadian, Dutch), from Visegrad } \\
\text { Fund, from European Youth } \\
\text { Foundation; }\end{array}$ & $\begin{array}{l}\text { European funds, limited primarily to means } \\
\text { of European Social Fund; situations in which } \\
\text { non-governmental organizations directly try } \\
\text { to obtain funds from the EU are rare; }\end{array}$ \\
\hline $\begin{array}{l}\text { Supranational } \\
\text { information } \\
\text { policy }\end{array}$ & $\begin{array}{l}\text { still developing 3rd sector in Poland has } \\
\text { also impact on the development of } \\
\text { efficient supranational information } \\
\text { flow, though still much remains to be } \\
\text { done (e.g. bilingual websites are still } \\
\text { not a rule); }\end{array}$ & $\begin{array}{l}\text { developed communication network; long } \\
\text { traditions of existence of non-governmental } \\
\text { organizations in Germany result in the fact } \\
\text { that Germany is an important element of } \\
\text { information flow, especially in the European } \\
\text { Union; }\end{array}$ \\
\hline $\begin{array}{l}\text { International } \\
\text { structure }\end{array}$ & $\begin{array}{l}\text { non-governmental organizations } \\
\text { created in Poland most often are } \\
\text { national, however, there are branches } \\
\text { of many organizations from outside the } \\
\text { boundaries of Poland; }\end{array}$ & $\begin{array}{l}\text { non-governmental organizations created in } \\
\text { Germany have their branches, especially in } \\
\text { neighbouring countries; }\end{array}$ \\
\hline
\end{tabular}

Source: (Balon, 2013). 


\section{Determinants of Operations of Polish NPOs and NGOs}

The extent to which the organization has adapted to challenges resulting from globalization defines the level of globalization of a NPO/NGO. Determinants used to measure this process are: objectives of an organization, international actions, partnership with foreign organizations, international personnel, supranational information policy and international structure. Gumkowska and Herbst (2006) focus on globalization factors in their research findings based on a group of 100 randomly selected Polish public benefit organizations from the database kept by the Klon/Jawor Association. The largest number of indications - 31 cases of the examined NPOs/NGOs indicated goals of the organization (Figure 1), which are related to problems caused by globalization in response to hazards arising in connection with it. Among goals adopted by the organizations most common were those related to environmental protection; other organizations defined themselves by supporting and maintaining democracy processes, such as: co-existence of nations and mutual tolerance, protection of civil liberties, care for equal treatment of women and men, protection of the rights of children, fight with tumours and other lifestyle diseases as well as help for victims of natural disasters and military conflicts (Domański, 2008, p. 252).

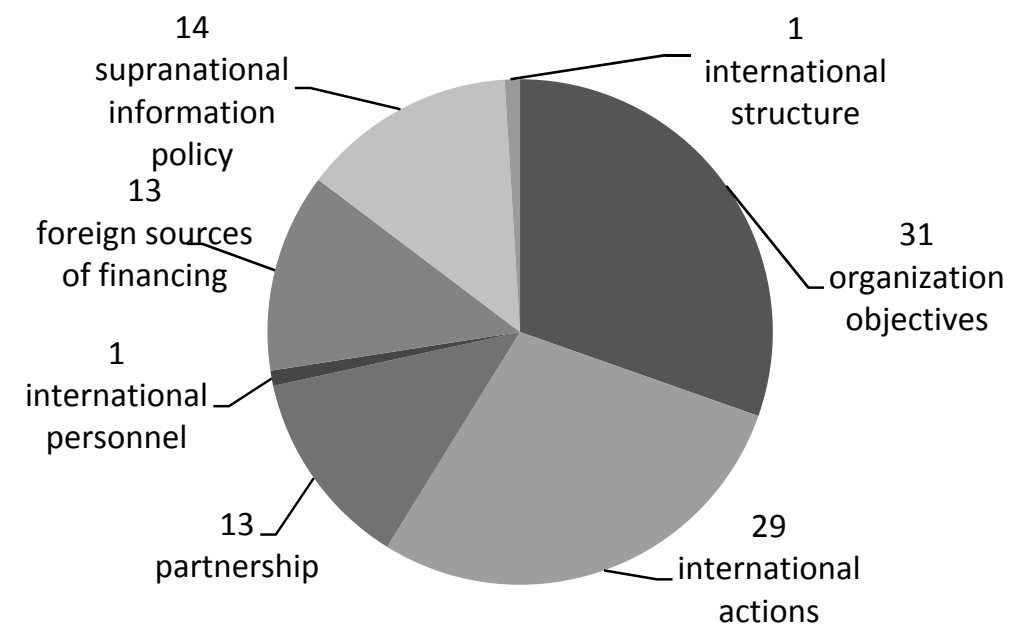

Figure 1. Presence of determinants of globalization in Polish non-governmental organizations Source: own compilation based on (Gumkowska \& Herbst, 2006).

29 times international actions were indicated, manifested in participation in internationally inspired and directed campaigns, projects and undertakings. Most often in this case the activity was connected with participation in conferences and trainings, constituting the basis for exchange of experiences on various dimensions (international flow of information). An organization can be both the organizer of such meetings and a participant. The determinant to classify them to this category is their international nature. In addition, we can mention cooperation with foreign partners: internships for students, foreign internships and teaching programmes. The next in line of most 
numerous indications is supranational information policy. Thanks to it, the recipients of message are not only local citizens, but thanks to multilingual websites or brochures and other printed documents people of other countries. Information policy was a little less frequently mentioned (13\%). In this context it was represented by the agreements concluded with different non-governmental organizations from abroad or membership in international organizations and associations. These international interactions mainly form the basis for implementation of common goals. The same percentage as for the information policy was assigned to acquiring financial sources. Gaining foreign sponsors still is not the forte of Polish non-profit organizations, but surely their actions in this field has been intensifying (Fudaliński, 2013). The lowest degree of globalization of Polish third sector organizations is represented by international personnel and structure. According to the research, the problems of globalization do not apply even to half of the Polish non-profit organizations. So, it can be concluded that the national third sector is in the initial phase of globalization. It is still, above all, focused on national needs where gradually problems of global nature occur, which are noticed by the organizations.

Little experience, resulting from the short time of existence of Polish organizations, must be named as one of the most important reasons for such a state of affairs. It is also influenced by limited amount of funds, resources, and volunteers. Certainly, along with the paying more attention to non-profit organizations in a holistic way, the degree of their globalization will increase. Such a holistic approach, will cause improvement in financial situation of the society, which, in turn, in the future will affect creation a realistically measurable model of NPOs and/or NGOs operating in the global dimension.

Table 4. Division of identified dysfunctions of non-governmental organizations in Poland

\begin{tabular}{|l|l|}
\hline \multicolumn{1}{|c|}{ Internal factors } & \multicolumn{1}{|c|}{$\begin{array}{c}\text { Factors related to implementation of activities } \\
\text { at the contact organization - environment }\end{array}$} \\
\hline $\begin{array}{l}\text { Lack of competences and skills of organization } \\
\text { management and ignorance of one's rights } \\
\text { and obligations }\end{array}$ & $\begin{array}{l}\text { Failure to comply with the law, especially concerning } \\
\text { taxes, business operations and contracting with donors }\end{array}$ \\
\hline $\begin{array}{l}\text { Using the reactions of compassion and } \\
\text { solidarity of the society in order to get } \\
\text { donations }\end{array}$ & $\begin{array}{l}\text { Vague connections with sponsors, lack of transparency in } \\
\text { relations }\end{array}$ \\
\hline $\begin{array}{l}\text { Criminal activity of some managers, aiming at } \\
\text { their own benefits (focus on profit) }\end{array}$ & $\begin{array}{l}\text { Establishing non-profit organizations only to gain } \\
\text { privileges offered by the legal system (state) to non- } \\
\text { governmental organizations }\end{array}$ \\
\hline $\begin{array}{l}\text { Failure of an organization to comply with } \\
\text { NPOs/NGOs legal regulations, nepotism }\end{array}$ & $\begin{array}{l}\text { Proceedings inconsistent with the principles of corporate } \\
\text { social responsibility (CSR) }\end{array}$ \\
\hline $\begin{array}{l}\text { Payment of high remuneration to organization } \\
\text { members }\end{array}$ & $\begin{array}{l}\text { Excessive orientation of non-governmental organizations } \\
\text { on commercialization }\end{array}$ \\
\hline Corruption & $\begin{array}{l}\text { Using free advertising and promotion in mass media } \\
\text { without proper correlation with activities conducted at an } \\
\text { appropriate level of professionalism }\end{array}$ \\
\hline $\begin{array}{l}\text { Failure to comply with the existing obligations } \\
\text { related to preparing financial and substantive } \\
\text { statements }\end{array}$ & $\begin{array}{l}\text { Blurred boundaries between non-profit and business } \\
\text { sectors, through rivalry with business units about financial } \\
\text { means }\end{array}$ \\
\hline $\begin{array}{l}\text { Establishing non-governmental organizations in } \\
\text { order to implement private initiatives and gain } \\
\text { related benefits }\end{array}$ & $\begin{array}{l}\text { Reversed structure of settlements and operating costs of } \\
\text { an organization - their greater part is internal costs (e.g. } \\
\text { wages), which results in lack of funds for implementation } \\
\text { of activities aimed at external recipients }\end{array}$ \\
\hline
\end{tabular}

Source: own study. 


\section{Pathologies and Dysfunctions of Non-Profit Organizations}

The sector of non-governmental organizations experiences many development limitations and encounters barriers, not only in Poland, but also in other countries. In many cases they are related to the nature of the three sectors and the roles and tasks assigned to them (Fudaliński, 2013, p. 39; Szymankiewicz, 2013). These problems also result from differences of organizational cultures, legal barriers and relate to the nature of activities performed (Wygnański, 2008, p. 7). The irregularities are also related to increasing commercialization with regard to the third sector in Poland and abroad (Table 4).

Dysfunctions of operations of non-profit organizations in Poland result from irregularities occurring both inside and outside an organization, and are associated with unethical relations with external environment. Problems that occur in the third sector are related mostly to the lack of knowledge and ignorance of the law, which contributes to the growth in abuses. Failure of organizations to comply with obligations related to preparing annual financial statements and failure of its members to comply with the provisions included in the Act also affects the development of the third sector. An important problem of the organization's dysfunctions of the non-profit sector is also activities bearing the signs of corruption when the founders act only for their own benefits. Blurred boundaries between sectors, competition for cash funds also adversely affect the development of non-governmental organizations in Poland.

Dysfunctions reported in table 5 show the existing development gap between the third sector in Poland and well-developed countries. Often it would be enough to apply simple mechanisms based on benchmarking methodology to avoid emergence of some dysfunctions and preventive actions would reduce the probability of specified pathologies. Undoubtedly their restriction may be stimulating for the dynamics of internationalization of operations of non-profit organizations and at the same time cause implementation of the broadly understood standards recognized as basic in countries, which in this respect already have much greater experience. At the same time it should be stated that non-profit profit organizations activities in well-developed countries also encounter numerous barriers and irregularities.

Sample dysfunctions of the third sector organizations in the international dimension, based on the example of Great Britain (Hayday, 2010; Gabrusewicz, 2008), include:

- non-profit organizations becoming similar to commercial companies, both in terms of management process and culture of work;

- large competition of social entities with business organizations, mainly for cash funds;

- merger of contracted organizations into consortiums to increase their liquidity, which cause smaller units are excluded from cooperation system;

- instability of the services system for the society, constant changes of contractors and subcontractors, which leads to dehumanization of support;

- disappearing of boundaries between the non-governmental and governmental sector.

The main dysfunctions present in the third sector in Great Britain include mainly excessive commercialization of social entities. Public services are contracted by the nonprofit organizations and business entities in the tender procedure. Therefore, non- 
governmental organizations, in order to acquire financial support, must compete with businesses (Kaim, 2011, pp. 297-300). The comparative analysis concerning differences in the scope of development of the non-profit organizations sector in Poland and Great Britain is informative (Bednarz, 2010; Edwardes, 2010; Leś, 2010), especially when comparing basic criteria showing the level and formula of their development (Table 5).

Table 5. Comparison of British and Polish model for NPOs/NGOs

\begin{tabular}{|c|c|c|}
\hline Properties & Great Britain & Poland \\
\hline $\begin{array}{l}\text { Applying the } \\
\text { subsidiarity principle }\end{array}$ & $\begin{array}{l}\text { The principle does not refer } \\
\text { only to the possibility to obtain } \\
\text { subvention, but regulates, } \\
\text { above all, division of } \\
\text { responsibilities between the } \\
\text { public and the private sector } \\
\text { with regard to providing social } \\
\text { services. }\end{array}$ & $\begin{array}{l}\text { In Poland this principle is applied to a smaller } \\
\text { extent, but readiness for common action is also } \\
\text { present. }\end{array}$ \\
\hline $\begin{array}{l}\text { Transparency of the } \\
\text { organization's } \\
\text { functioning }\end{array}$ & $\begin{array}{l}\text { There is high transparency in } \\
\text { non-governmental } \\
\text { organizations' operations; an } \\
\text { important element is efficient, } \\
\text { reliable conduct of control and } \\
\text { making reliable financial } \\
\text { statements. }\end{array}$ & $\begin{array}{l}\text { Not always transparency of the organization's } \\
\text { functioning is maintained, due to failure of the } \\
\text { organization to keep reporting obligations; } \\
\text { there is often no transparency in this respect. }\end{array}$ \\
\hline $\begin{array}{l}\text { Cooperation } \\
\text { between sectors }\end{array}$ & $\begin{array}{l}\text { High involvement of the state } \\
\text { in helping non-profit } \\
\text { organizations, trust between } \\
\text { sectors is present. }\end{array}$ & $\begin{array}{l}\text { The state to a smaller extent is involved in non- } \\
\text { profit organizations activities, low trust } \\
\text { between sectors is present; awareness in this } \\
\text { scope is still being built. }\end{array}$ \\
\hline Commercialization & $\begin{array}{l}\text { Non-profit organizations to a } \\
\text { large extent became similar to } \\
\text { commercial companies, aiming } \\
\text { at profit and rivalry for cash } \\
\text { funds. }\end{array}$ & $\begin{array}{l}\text { Non-governmental organizations more and } \\
\text { more often aim at commercialization. }\end{array}$ \\
\hline $\begin{array}{l}\text { Professionalism and } \\
\text { competencies of } \\
\text { management }\end{array}$ & $\begin{array}{l}\text { Larger experience and } \\
\text { traditions taking account of the } \\
\text { special character of non-profit } \\
\text { organizations management }\end{array}$ & $\begin{array}{l}\text { Poland lacks in able manager, there is frequent } \\
\text { ignorance of basic canons of management } \\
\text { process; awareness in the need of } \\
\text { professionalization of the management process } \\
\text { is slowly growing and is fragmentary; there is } \\
\text { strong sense of implementation of the adopted } \\
\text { mission, without taking into account } \\
\text { professional management to a sufficient } \\
\text { extent. }\end{array}$ \\
\hline
\end{tabular}

Source: own study based on (Hayday, 2010; Edwardes, 2010, pp. 123-128).

Although, as it is determined, sometimes excessive commercialization of the third sector in Great Britain is not a favourable phenomenon, nevertheless it is estimated that Polish non-profit organizations may be more exposed to commercialization than the British ones because Polish society is not comparably rich and still does not have sufficiently well-developed philanthropic culture. It is also important to notice that Great Britain has its high level of non-profit organizations operations thanks to proper cooperation with public administration.

In this sense Poland should seek benchmarks in order to construct model solutions for optimizing the process of the third sector development, but also for avoiding 
mistakes (Table 6). From this point of view, you can optimize solutions stimulating the development not only in quantitative sense but, first of all, in qualitative sense.

Table 6. Specification of pathology of non-profit organizations in Poland and other countries

\begin{tabular}{|c|c|c|c|}
\hline Country & $\begin{array}{l}\text { Pathologies in the } \\
\text { organizational field }\end{array}$ & $\begin{array}{l}\text { Pathologies in the financial } \\
\text { field }\end{array}$ & $\begin{array}{l}\text { Pathologies in the social } \\
\text { field, }\end{array}$ \\
\hline Poland & $\begin{array}{l}\text { - not undertaking } \\
\text { actions caused by } \\
\text { the lack of structures } \\
\text { and financial } \\
\text { possibilities, } \\
\text { - lack of proper } \\
\text { equipment, } \\
\text { - aversion to improve } \\
\text { the quality of } \\
\text { provided services, } \\
\text { - operations in the } \\
\text { mode of temporary } \\
\text { contracts - contracts } \\
\text { of employment are } \\
\text { rare, } \\
\text { - operations in areas } \\
\text { that are subsidized, } \\
\text { not in those that } \\
\text { require assistance, } \\
\text { - lack of full respect of } \\
\text { the Act on public } \\
\text { benefit activities and } \\
\text { voluntary service, } \\
\text { - alienation of the } \\
\text { third sector - } \\
\text { activities on their } \\
\text { own account. }\end{array}$ & $\begin{array}{l}\text { - lack of appropriate, fully } \\
\text { standardized financial } \\
\text { statements, } \\
\text { - disproportions in received } \\
\text { assistance, } \\
\text { - no revenue or its minimum } \\
\text { level in the case of some } \\
\text { organizations, } \\
\text { - disproportions in the size of } \\
\text { budgets, } \\
\text { - relatively large part of funds } \\
\text { spent on administrative costs } \\
\text { and wages (which sometimes } \\
\text { means a way of negative } \\
\text { financial drainage of } \\
\text { organizations). }\end{array}$ & $\begin{array}{l}\text { - decreasing popularity of } \\
\text { voluntary service, } \\
\text { - low prestige of work, } \\
\text { - periodical (occasional) } \\
\text { charitable drives of the } \\
\text { Poles (WOŚP) - lack in this } \\
\text { respect of well-established, } \\
\text { permanent patterns of } \\
\text { behaviour, } \\
\text { - uncritical assessment of the } \\
\text { representatives of } \\
\text { organizations. }\end{array}$ \\
\hline $\begin{array}{l}\text { The United } \\
\text { States of } \\
\text { America }\end{array}$ & $\begin{array}{l}\text { - too many court } \\
\text { trials, } \\
\text { - too many legal } \\
\text { regulations, } \\
\text { - using the law to } \\
\text { exercise pressure, } \\
\text { - sometimes incorrect } \\
\text { measurement of } \\
\text { results of operations. }\end{array}$ & $\begin{array}{l}\text { - corruption, } \\
\text { - lack of proper financial } \\
\text { reporting in private } \\
\text { foundations. }\end{array}$ & $\begin{array}{l}\text { - treating activities for the } \\
\text { benefit of non-profit } \\
\text { organizations as sometimes } \\
\text { an obligation, and not an } \\
\text { expression of natural } \\
\text { willingness. }\end{array}$ \\
\hline $\begin{array}{l}\text { Countries } \\
\text { of the } \\
\text { former } \\
\text { USSR }\end{array}$ & $\begin{array}{l}\text { - lack of appropriate } \\
\text { structures, } \\
\text { - lack of qualifications, } \\
\text { knowledge in the } \\
\text { scope of running } \\
\text { non-profit } \\
\text { organizations. }\end{array}$ & $\begin{array}{l}\text { - shortage of financial measures } \\
\text { to continue operations, } \\
\text { - using non-profit organizations } \\
\text { for illegal financial flows. }\end{array}$ & $\begin{array}{l}\text { - reluctance of citizens } \\
\text { towards social activities } \\
\text { caused by experiences from } \\
\text { the previous political } \\
\text { system, } \\
\text { - lack of developed standards } \\
\text { of conduct and cultural } \\
\text { support in this respect. }\end{array}$ \\
\hline
\end{tabular}

Source: own study.

Cooperation of non-profit organizations sector with the state is undoubtedly an important element which helps to improve and advance the society. Non-governmental 
organizations operating in Poland should refer to well-developed countries while looking for good practices. In Poland we need social contracts which would regulate contacts of public administration with civil initiatives. In addition, an important goal of formalization of cooperation of the state with the third sector would be the improvement in efficiency and effectiveness in providing social services. Increase in cooperation of Polish social organizations with governmental administration would strengthen the culture of interdependence of the non-governmental sector with the state, which would have a positive impact on the development of financial and political institutionalisation of Polish civil initiatives. Non-profit organizations in Poland undoubtedly require some support from government administration, which will enable non-governmental organizations to achieve important social goals, and hence the state should show the willingness to help and support non-profit entities. While seeking solutions concerning improvement in operations of non-governmental organisations in Poland, we also should take into consideration the ways of control exercised over these organizations in other countries.

\section{CONCLUSIONS}

Summarizing, the development of non-profit organization sector in Poland undoubtedly depends on the possibility of opening to international aspects and aiming at global dimension. In this context, internationalization and globalization are determinants of third sector development and any dysfunctions in its operations should be eliminated. Therefore, it is advisable to adopt a special algorithm based on elements concerning:

- monitoring present pathological phenomena,

- undertaking preventive actions in this respect,

- creating mechanisms of their elimination,

- seeking benchmarks with regard to solutions verified in the whole world,

- creating a code of good practices related to non-profit organizations operations,

- supporting initiatives stimulating internationalization of the third sector,

- building awareness of the civil society in the international dimension.

\section{REFERENCES}

Balon, K. (2013). Gospodarka społeczna w Niemczech - wybrane aspekty, Retrieved on April 7, 2013 from http://wiadomosci.ngo.pl/files/ekonomiaspoleczna.pl/public/Raport_Otwarcia/Balon_ GospSpol_Niemcy.pdf

Bebington, A.J., Hickey, S., \& Mitlin, D.C. (2007). Can NGOs Make a Difference?, The Challenge of Development Alternatives, London - New York: Zed Books.

Bednarz, P. (2010). Najlepsze praktyki w zakresie konsultacji społecznych w Wielkiej Brytanii. Warszawa: Instytut Badań nad Demokracją i Przedsiębiorstwem Prywatnym.

Bogacz-Wojtanowska, E. (2011). Współdziałanie organizacji pozarzq̨dowych i publicznych. Kraków: Instytut Spraw Publicznych Uniwersytetu Jagiellońskiego.

Breński, W., \& Oleksiuk, A. (2008). Strategiczne szanse polskiej gospodarki w kontekście globalizacji. Warszawa: Difin.

Courtney, R. (2002). Strategic Management for Voluntary Nonprofit Organizations. London-New York: Routledge. 
Daszkiewicz, N., \& Wach, K., (2012). Internationalization of SMEs: Context, Models and Implementation. Gdańsk: Gdańsk University of Technology Publishers.

Domański, J. (2008). Strategie przedsiębiorstw. Warszawa: Szkoła Głowna Handlowa.

Drucker, P.F. (1990). Managing a Non-Profit Organization. Principles and Practice. New York: Harper Collins.

Dworecki, Z., \& Romanowska, M. (Eds.). (2008). Strategie przedsiębiorstw w otoczeniu globalnym. Warszawa: Szkoła Główna Handlowa.

Edwardes, J. (2010). Rola i modele organizacji pożytku publicznego w Wielkiej Brytanii. Warszawa: Polish Donors Forum.

Ernst \& Young (2010). Waking up to the new Economy: Ernst \& Young's 2010 European attractiveness survey. Paris.

Fudaliński, J. (2013). Perspektywy rozwoju zarzqdzania społecznego w sektorze organizacji non profit w Polsce. Warszawa: Difin.

Gabrusewicz, T. (2008). Standardy etyki i odpowiedzialności dla sektora non-profit. Monitor Rachunkowości i Finansów, 1.

Gerencser, M., Van Lee, R., Napolitano, F., \& Kelly, Ch. (2008). Megacommunities: How Leaders of Gavernment Business and Non-Profits Can Tackle Today's Global Challenges Together. New York: Palgrave Macmillan.

Gumkowska, M., \& Herbst, J. (2006). Podstawowe fakty o organizacjach pozarzqdowych. Raport 2006, Warszawa: Klon/Jawor.

GUS (2012). Społeczeństwo informacyjne w Polsce. Warszawa: Główny Urząd Statystyczny.

Hayday, M. (2010). Warunki rozwoju ekonomii społecznej w Wielkiej Brytanii. Warszawa: Bank DnB NORD Polska S.A.

Kiendl-Wendner, D., \& Wach, K. (Eds.). (2014). International Competitiveness in Visegrad Countries: Macro and Micro Perspectives. Graz: Fachhochschule Joanneum.

Kaim, A. (2011), Przeciwdziałanie ubóstwu i wykluczeniu a komercjalizacja organizacji pozarzqdowych. Rozprawa doktorska. Gdańsk: Instytut Pedagogiki Uniwersytetu Gdańskiego.

Leś, E. (Ed.). (2010). Analiza porównawcza modeli współpracy administracji publicznej z organizacjami not for profit w wybranych państwach Unii Europejskiej. Warszawa: Collegium Civitas.

Najda, M., \& Wach, K. (2005). Impact of integrated European business environment on SMEs cooperation strategies. Ekonomia, 17, 123-139.

Przybylska, K. (2005). Proces internacjonalizacji przedsiębiorstwa w teorii ekonomicznej. Zeszyty Naukowe WSE w Bochni, 3

Przybylska, K. (2013). Born Global: nowa generacja małych przedsiębiorstw. Kraków: Fundacja Uniwersytetu Ekonomicznego w Krakowie.

Rybiński, K. (2007). Globalizacja w trzech odsłonach. Warszawa: Difin.

Szczepankowska, A. (2011). Europa wobec globalizacji. Toruń: Wyższa Szkoła Bankowa. Retrieved on April 1, 2011, from http://www.konferencja.edu.pl/ref8/pdf/pl/SzczepankowskaTorun.pdf

Szymankiewicz, M.J. (2013). Collaborative Advantage in Public and Social Services: the Case of Poland. Entrepreneurial Business and Economics Review, 1(4), 71-81.

Szymański, W. (2004). Interesy i sprzeczności globalizacji. Wprowadzenie do ekonomii ery globalizacji. Warszawa: Difin. 
Tyrakowski, M. (2013). Rola organizacji pozarzqdowych w rozwiqzzywaniu problemów społecznych, Retrieved on April 2, 2013, from http://znze.wsiz.rzeszow.pl/z04/9_Michal_Tyrakowski _Rola.pdf

Wach, K. (2012). Europeizacja małych i średnich przedsiębiorstw: rozwój przez umiędzynarodowienie. Warszawa: PWN

Wach, K. (2014). The Role of Knowledge in the Internationalisation Process: An Empirical Investigation among Polish Businesses. In (Eds.), D. Kiendl-Wendner, \& K. Wach, International Competitiveness in Visegrad Countries: Macro and Micro Perspectives (pp. 143157). Graz: Fachhochschule Joanneum.

Wach, K., \& Wehrmann, C. (2014). Entrepreneurship in International Business: International Entrepreneurship as the Intersection of Two Fields. In (Eds.), A.S. Gubik, \& K. Wach, International Entrepreneurship and Corporate Growth in Visegrad Countries. Miskolc: Miskolc University.

Wygnański, J. (2008). Ekonomizacja organizacji pozarzqdowych. Możliwość czy konieczność?, Warszawa: Klon/ Jawor.

\section{Author}

\section{Janusz Fudaliński}

Associate Professor of Management of the Department of Management Strategy and Development of Organizations at the Faculty of Economics and International Relations of the Cracow University of Economics (Poland). His research interests include strategic management in non-profit organisation.

\section{Correspondence to:}

Dr hab. Janusz Fudaliński

Department of Management Strategy and Development of Organizations

Cracow University of Economics

ul. Rakowicka 27, 31-510 Kraków, Poland

janusz.fudalinski@uek.krakow.pl

Published by Centre for Strategic and International Entrepreneurship - Krakow, Poland 